\title{
Crop Productivity, Land Degradation and Poverty Nexus in Delta North Agricultural Zone of Delta State, Nigeria
}

\author{
F. O. Aigbe $^{1} \&$ R. A. Isiorhovoja ${ }^{2}$ \\ ${ }^{1}$ Department of Agricultural Economics, Delta State University, Asaba Campus, Asaba, Nigeria \\ ${ }^{2}$ Department of Agricultural Economics and Extension, Delta State University, Asaba Campus, Asaba, Nigeria \\ Correspondence: R. A. Isiorhovoja, Department of Agricultural Economics and Extension, Delta State University, \\ Asaba Campus, Asaba, Nigeria. E-mail: straakpo@yahoo.com
}

Received: December 18, 2012 Accepted: January 27, 2013 Online Published: March 15, 2013

doi:10.5539/jas.v5n4p85

URL: http://dx.doi.org/10.5539/jas.v5n4p85

\begin{abstract}
This paper examined the nexus among crop productivity, land degradation and poverty in Delta North Agricultural Zone of Delta State, Nigeria. The hypothesis was that there is no significant relationship among crop productivity, land degradation and poverty in the study area A Multistage sampling technique was used to collect data from 150 respondents. Data were analyzed using percentages and Logit regression. In the regression analysis of Determinants of Crop Productivity, the adjusted R-square showed that about 46 percent of the variability in crop productivity was due to the explanatory variables. The F-stat of 21.41 was significant $\mathrm{P}=0.01$. All significant variables were positively related to the farmers' crop productivity. The weighted measure of poverty was employed to determine the poverty line as $\$ 5,383.98$. The logit model estimated the determinants of poverty in the study area. The model was well fitted with the log-likelihood function $(-54.39)$ and the Chi-square $\chi^{2}(98.74)$ significant at $1 \%$ level and different variables being significant in the model. The estimated household size variable has a positive coefficient of 0.84 at $1 \%$ significance level. The dependency ratio $\left(\mathrm{X}_{4}\right)$ coefficient of -0.52 was significant $\mathrm{p}=0.05 \%$. The value of elasticity showed that if dependency ratio decreases by one percent, the probability of being poor will increase by 0.13 percent. Household farm income $\left(\mathrm{X}_{5}\right)$ coefficient was found to be significant at $1 \%$ and negatively related to poverty status. Also the marginal analysis revealed that if farm income increases by 1 percent, the poverty status will remain unchanged. Land ownership $\left(\mathrm{X}_{13}\right)$ variable has a positive coefficient of 1.07 at $10 \%$ significant level. Agricultural information $\left(\mathrm{X}_{14}\right)$ was also found to be statistically significant at $5 \%$ level but with negative coefficient of 1.56 . We recommend that Policy on land management practices and natural resource exploitation should be reviewed or put in place where not existing and adhered to strictly by all relevant bodies and individuals as it will go a long way to conserving the natural resources and promoting crop yields with resultant increased farm income, all things being equal. Secondly, that family planning policy/programme of a maximum of four children to a family be revisited with a view to implementing it rigorously if the problems of large family size and unemployment are to be effectively addressed in the medium to long term.
\end{abstract}

Keywords: crop productivity, land degradation, poverty, nexus, Nigeria, household income, family planning

\section{Introduction}

Land degradation, low and declining agricultural productivity (crop inclusive) and poverty are severe and interrelated in Nigeria. Declining soil fertility, which limits crop yields, is a particularly serious and widespread problem. For thousands of years, agriculture has been the economic activity which is most essential to human survival and well-being. It has also been the economic sector which most affects and is most dependent on the natural environment (Enete \& Amusa, 2010).

The capacity of the agricultural sector to play its economic role has however suffered many setbacks in recent times. The rate of growth in the sector was far less than the rate of population increase. Higher demand as a result of population growth and urbanization, as well as the lack of alternative opportunities in rural areas, is putting pressure on agriculture to increase production, resulting in degradation of the land. The FAO (2010) reported that 925 million people were undernourished with Sub-Saharan Africa taking a toll of more than 234 million people. 
Land degradation is the reduction in the soil's ability to contribute to crop production (Blaike \& Brookfield, 1987) and a change to land that makes it less useful for human beings (Wasson, 1987). Examples of land degradation can be found in erosion, salinization, waterlogging, vegetation depletion, fertility loss, soil structure change and pollution of soil. In each case the focus is on the physical or biological effects. Land-use methods are regarded as the ultimate causes of degradation.

Poverty is a multidimensional problem, embedded in a complex and interconnected political, economic, cultural, and ecological system (Thorbecke, 2005). Measurement of poverty can include material deprivation, isolation, alienation, dependence, and lack of participation or freedom of choices of assets, vulnerability and insecurity.

Vosti and Reardon (1997) present an interesting conceptual model of the linkages between poverty and the environment that helps to highlight the complexity of the interrelationships. Poverty is seen to be the product of "asset" components comprising natural resources, human resources, on-farm resources, community-owned resources and social and political capital. These factors determine household and village behaviour in terms of income generation, consumption, investment in assets, migration and human fertility. These behaviours in turn has implications for the use and management of the natural resource component for agricultural production asset component of poverty.

The problem of sustaining growth in agricultural production in many developing countries emanates from unplanned land use and inability to give adequate attention to the physical, biological and ecological implication of agricultural intensification (Cleaver \& Schreiber, 1993, 1994; Barbier, 2001). Therefore, the yields of some tropical crops have now started to decrease and the reserves of unused land areas are decreasing, thereby leading to depletion of the natural resource base of agricultural growth and development.

In Nigeria, persistent stagnation in agricultural production is a matter of serious concern. Although outputs in some crops have recently increased, most of the increases resulted from increased in land areas cultivated (Oyekale, 2012). Increasing crop production is therefore putting a lot of pressure on the forest, and it is unlikely that this will be sustainable as population further increases.

The Delta North Agricultural Zone of Delta State contributes significantly to the production of major food crops in the State. The State is in the rainforest vegetation with loamy soil hence good for farming. Amongst the crops cultivated are cassava, yam, plantain and maize.

The objectives of this study were to (i) examine the crop productivity of farmers (ii) identify the land degradation problems (iii) estimate the poverty status of farm households and (iv) ascertain the determinants of poverty in the study area. There is no significant relationship among crop productivity, land degradation and poverty in the study area.

\section{Materials and Method}

\subsection{Study Area}

The study was carried out in 2006 in the Delta North Agricultural Zone of Delta State in Nigeria. The zone is made up of nine (9) local government areas of the twenty five (25) local government areas of Delta State.

\subsection{Source and Method of Data Collection}

Data were collected from both primary and secondary sources. Copies of a structured questionnaire were used to collected data from primary sources. Respondents were drawn through a multistage sampling technique. Three local government areas (LGAs) were randomly drawn from the nine LGAs in the agricultural zone. This was followed by random drawing of five (5) villages listed at the local government secretariats from each of the already drawn three LGAs. Ten (10) farming households were randomly selected from each of the selected villages using a list of Household that was obtained from the Agricultural Development Programmes (ADP) headquarters. The study was therefore carried out using a sample size of 150 respondents.

\subsection{Crop Productivity Model}

The traditional production function was used to examine the crop productivity of farmers in the study area. The crop production model is stated thus;

$$
\mathrm{Y}=\mathrm{c}+\mathrm{B}_{1} \mathrm{Q}_{1}+\mathrm{B}_{2} \mathrm{Q}_{2}+\mathrm{B}_{3} \mathrm{Q}_{3}+\mathrm{B}_{4} \mathrm{Q}_{4}+\mathrm{B}_{5} \mathrm{Q}_{5}+\mathrm{B}_{6} \mathrm{Q}_{6}+\mathrm{e}
$$

Where:

$\mathrm{Y}=$ value of crop produced by household;

$\mathrm{Q}_{1}=$ Household size; 
$\mathrm{Q}_{2}=$ years spent in school (in years);

$\mathrm{Q}_{3}=$ Farm size in hectare;

$\mathrm{Q}_{4}=$ Years in farming;

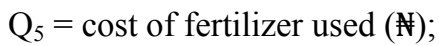

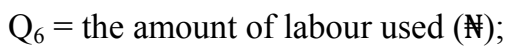

$\mathrm{e}=$ error term;

$\mathrm{c}=$ constant

\subsection{Poverty Measure}

Poverty line is the value of income or consumption expenditure necessary for a minimum standard of living. The poverty line used for this study was the two-third of mean per capita household expenditure (2/3 MPCHHEXP). This approach is similar to the one adopted by the World Bank (1996) in its poverty assessment of Nigeria and by FOS (1999).

Total per capita expenditure was used as a measure of the standard of living of households.

$$
\text { Per Capita Expenditure }=\frac{\text { Total household monthly expenditure }}{\text { Household size }}
$$

The mean per capita household expenditure (MPCHHE) was calculated thus:

\section{$\frac{\text { Total per capita household expenditure }}{\text { Total number of households }}$}

From the resulting mean per capita household expenditure, two line sets relative to the standard of living were established for the respondents, namely:

i. The moderate poverty line equivalent to two-thirds of the mean per capita household expenditure.

ii. A core poverty line equivalent to one-third of the mean per capita household expenditure.

By this, households were grouped into three poverty categories as follows:
a. Core poor
b. Moderately poor
c. Non-poor

Any household whose expenditure fell below the moderate poverty line (two thirds of mean per capita household expenditure) was regarded as being poor while those above it were regarded as non-poor. Series of models have been developed in poverty measurement. Among these were the Sen Index (Sen, 1976), the $P \alpha$ weighted poverty measure (Foster, Greer, \& Thorbecke, 1984) (FGT), the Human development index (HDI) (UNDP, 1990). The most widely used, however, is the FGT's $P \alpha$ weighted poverty measure and this is used in this study.

The Foster, Greer, and Thorbecke (1984) weighted measure of poverty is based on income or expenditure of the household and it is a class of parametric poverty measure that satisfies Sen's transfer axiom which requires that when income is transferred from the poor to the richer household, it induces an increase in the poverty measure. It includes factors that are sensitive to changes in inequality among the poor, changes in income shortfall and changes in the number of the poor. It is expressed as:

Where

$$
P \alpha=n^{-1} \sum_{i=1}^{m}(z i-y i / Z)^{\alpha}
$$

$\mathrm{n}=$ total number of households;

$\mathrm{yi}=$ income (or expenditure) of person in the $i$ th household;

$Z=$ Poverty line (using $2 / 3$ of mean per capita monthly household expenditure);

$\mathrm{M}=$ Number of households with income or consumption expenditure below the poverty line;

$\mathrm{n}=$ the number of people in the population;

$\alpha=$ the degree of poverty aversion.

Different values of $\alpha$ in equation 2 give different poverty measures. 
When $\alpha=0$, it gives the head count or poverty incidence. This is because the term in brackets is always 1 , so the summation gives us the total number of people in poor households, which, when divided by n, gives us the proportion of people living in poor households.

$$
P \alpha=n^{-1} \sum_{i=1}^{m}(z i-y i / Z)^{0}
$$

It is useful in testing the effectiveness, over time, space or subgroup of policies intended to lessen the relative number of poor people. Poverty is said to decline if the population of the poor decreases. Although it satisfies the focus axiom of poverty, it does not indicate the extent of poverty intensity as well as the severity of poverty i.e. it does not indicate the extent of inequality.

When $\alpha=1$, it measures the depth of poverty. P1 takes into account not just how many people are poor but how poor they are on average. It is equal to the incidence of poverty multiplied by the average percentage gap between the poverty line and the income of the poor. It implies uniform concern about the depth of poverty since it weighs the different income gaps of the poor equally. It gives the proportion of the poverty line required to lift a poor person out of poverty i.e.

$$
P 1=n^{-1} \sum_{i=1}^{m}(z i-y i / Z)^{1}
$$

When $\alpha=2$, it captures the severity of poverty (or squared poverty gap). It takes into account not just how many people are poor and how poor they are but also the degree of income inequality among poor households. It gives the distribution of income or expenditure among the poor only i.e. it attaches greater weight to the poverty of the poorest than of those just below the poverty line. It is equal to the incidence of poverty multiplied by the average squared percentage gap between the poverty line and the income of the poor.

$$
P 2=n^{-1} \sum_{i=1}^{m}(z i-y i / Z)^{2}
$$

Equation 5 satisfies the focus, monotonicity and transfer axioms of poverty measure. It should be noted that the higher the $P \alpha$ measures, the higher the poverty level.

\subsection{Logit Model}

The poverty line was used to dichotomize the households into poor and non poor (Nzenwa \& Oboh, 2005). Empirical studies on the determinants of poverty have used different methodologies. These include the classical regression approach to estimate the per capita expenditure function (Grooteart, 1997), Probit estimation (Taddesse et al., 1999) and Olaniyan (2000).

This study followed the logit specification since the dependent variable is dichotomous, which in this case are the poor and non-poor. The dependent variable took the value of zero (0) or one (1) where 1 represents being poor and 0 otherwise.

The empirical form of the model is specified as

$$
\begin{gathered}
Y_{i}=\beta_{0}+\beta_{1} X_{1}+\beta_{2} X_{2}+\beta_{3} X_{3}+\beta_{4} X_{4}+\beta_{5} X_{5}+\beta_{6} X_{6}+\beta_{7} X_{7}+\beta_{8} X_{8}+\beta_{9} X_{9}+\beta_{10} X_{10}+\beta_{11} X_{11}+\beta_{12} X_{12}+\beta_{13} X_{13} \\
+\beta_{14} X_{14}+\beta_{15} X_{15}+e
\end{gathered}
$$

Where

$\mathrm{Y}_{\mathrm{i}}=$ poverty status ( 1 if poor; 0 otherwise);

$\mathrm{X}_{1}=$ Age of household head (in years);

$\mathrm{X}_{2}=$ Educational level of household head (number of years spent in school);

$\mathrm{X}_{3}=$ Household size;

$\mathrm{X}_{4}=$ dependency ratio;

$\mathrm{X}_{5}=$ Household farm income $(\mathrm{N})$;

$\mathrm{X}_{6}=$ Household off-farm income ( $\left.\mathrm{N}\right)$;

$\mathrm{X}_{7}=$ Years of farming experience of the household head;

$\mathrm{X}_{8}=$ Gender of household head (1 if male; 0 otherwise); 
$\mathrm{X}_{9}=$ Ownership of house (1 if owned; 0 otherwise);

$\mathrm{X}_{10}=$ Marital status of the household head;

$\mathrm{X}_{11}=$ Participation in organizations ( 1 if yes; 0 otherwise);

$\mathrm{X}_{12}=$ Occupation of the household head (part - time or full-time);

$\mathrm{X}_{13}=$ Ownership of land ( 1 if owned; 0 otherwise);

$\mathrm{X}_{14}=$ Other sources of agricultural information;

$\mathrm{X}_{15}=$ Investment in land Management Practices ( $\mathbb{*}$ );

$\beta_{\mathrm{i}}=$ coefficients of exogenous variables;

$\mathrm{e}=$ error term

\section{Results and Discussion}

Table 1 show that the average age of respondents in the study area was about 55 years and the educational level of respondents was 9 years of formal education. This could have effect on crop production, land degradation and poverty in the study area. The low level of education in the study area could deprive the people of adopting farming practices that recognize land conservation techniques and this could lead to poverty. The dependency ratio was about 5 persons to one. There was an average of 8 persons in a household and this shows that majority of respondents have large household size. This could be an advantage in the availability of labour for farming activities. The average number of years of farming experience was about 25 years. High level of experience will enhance their knowledge of appropriate land management and crop husbandry techniques, all things being equal.

Table 1. Distribution of respondents by socio economic characteristics

\begin{tabular}{lcccc}
\hline & Total & Minimum & Maximum & Mean \\
\hline Age & 150 & 30 & 84 & 55.03 \\
Educational level & 150 & .00 & 26 & 9.34 \\
Dependency Ratio & 150 & .00 & 10 & 4.71 \\
Working members of Household & 149 & .00 & 12 & 3.35 \\
Years of farming experience & 150 & 1.00 & 60 & 25.03 \\
Household Size & 150 & 1.00 & 24 & 8.31 \\
\hline
\end{tabular}

Source: Field Survey, 2006.

Empirical evidence shows that majority of respondents ( 87.3 percent) were male farmers. Also, majority of the respondents ( 82 percent) were married, 12 percent of them were widows. Farmers also engaged in other forms of livelihood activities which could be a coping strategy for poverty reduction.

\subsection{Production Function}

The particular form of the production function is determined by the elasticity of factor substitution. The elasticity of factor substitution is a measure of the ease with which the varying factor can be substituted for others. The double log function has a unitary elasticity of factors' substitution unlike both the linear production function which assumes infinite elasticity of substitution and Leontief production function which assumes zero elasticity of substitution. The double log functional form was considered as lead equation.

The adjusted R-square shows that about 46 percent of the variability in crop productivity was due to the explanatory variables. Also, the F-stat of 21.41 was significant at $1 \%$ level. Three out of six the explanatory variables were significant at different levels of significance. Farm size $\left(\mathrm{Q}_{3}\right)$ was significant at $1 \%$ and positively related to crop output. This means that the larger the farm size the higher the farmer's crop productivity; years of farming experience $\left(\mathrm{Q}_{4}\right)$ was also significant at $1 \%$ level. All significant variables were positively related to crop productivity. This implies that as they increase the $\mathrm{f}$ crop productivity also increases. 
Table 2. Regression result of determinants of crop productivity

\begin{tabular}{llll}
\hline Variable & Coefficient & Std. Error & t-Statistic \\
\hline LOG $\left(Q_{1}\right)$ & 0.13 & 0.09 & 1.26 \\
$\operatorname{LOG}\left(Q_{2}\right)$ & 0.11 & 0.09 & 1.14 \\
$\operatorname{LOG}\left(Q_{3}\right)$ & 1.34 & 0.18 & $7.43^{*}$ \\
$\operatorname{LOG}\left(Q_{4}\right)$ & 0.14 & 0.05 & $2.82^{*}$ \\
$\operatorname{LOG}\left(Q_{5}\right)$ & 0.19 & 0.07 & 2.58 \\
$\operatorname{LOG}\left(Q_{6}\right)$ & 0.01 & 0.09 & 0.11 \\
C & 6.81 & 0.96 & 7.05 \\
R-squared & 0.48 & & \\
Adjusted R-squared & 0.46 & & \\
F-stat & 21.41 & & \\
\hline
\end{tabular}

Source: Computer printout of the data in September 2006.

The dependent variable is value of crop produced by household.

* Significant level at $1 \%$.

** Significant level at $5 \%$.

\subsection{Land Degradation}

Table 3. Distribution of respondents by erosion problems

\begin{tabular}{lll}
\hline Type of erosion & Frequency & Percent \\
\hline splash erosion & 99 & 66.0 \\
sheet erosion & 21 & 14.0 \\
no erosion problem & 20 & 13.3 \\
Cant say & 10 & 6.7 \\
Total & 150 & 100.0 \\
\hline
\end{tabular}

Source: Field Survey, 2006.

Table 3 revealed that about $80.0 \%$ of the respondents had erosion problem while $13.3 \%$ of the respondents did not experience erosion problems on their farmland. Erosion was used to capture and degradation problem in the study.

\subsection{Poverty Analysis}

\subsubsection{Poverty Line Determination}

Through the Foster, Greer, and Thorbecke (1984) weighted measure of poverty; the poverty line was established as N5383. This means that any household that spent above $\$ 5383$ over the monthly period of time was regarded as not poor, if, otherwise, then poor.

\subsubsection{Poverty Incidence, Depth and Severity}

The result shows that there was a poverty incidence of $0.47\left(\mathrm{P}_{\alpha}=0(0.47)\right)$. The findings imply that 47 percent of the respondents were poor. Also the poverty depth or gap was estimated at $0.17\left(\mathrm{P}_{\alpha}=1(0.17)\right)$ while the severity of poverty was $0.09\left(\mathrm{P}_{\alpha}=2(0.09)\right)$. The poverty gap index of 0.17 means that about 17 percent increase in income will lift the poor out of poverty. Also, the severity index of 0.09 implies that income distribution among the poor is 9.0 percent of the total income generated. 


\subsection{Logit Model Analysis}

Table 4. Logit regression model of poverty determinants among farmers

\begin{tabular}{cccc}
\hline Variables & Coefficients & t-stat & Marginal effect \\
\hline Constant & -3.77 & -2.2 & -0.93 \\
X1 & 0.02 & 0.56 & 0.00 \\
X2 & 0.01 & 1.30 & 0.00 \\
X3 & $0.84^{*}$ & 4.27 & 0.20 \\
X4 & $-0.52^{* *}$ & -2.96 & -0.13 \\
X5 & $-0.23^{*}$ & -3.57 & 0.00 \\
X6 & 0.00 & 0.00 & 0.00 \\
X7 & -0.02 & -0.53 & 0.00 \\
X8 & 0.85 & 0.95 & 0.21 \\
X9 & 0.01 & 0.02 & 0.00 \\
X10 & -0.01 & -0.14 & -0.01 \\
X11 & -0.07 & -0.27 & 0.00 \\
X12 & 0.25 & 0.64 & 0.06 \\
X13 & 1.07 & 1.68 & 0.26 \\
X14 & $-1.56^{* *}$ & -2.66 & -0.38 \\
X15 & 0.41 & 0.81 & 0.10 \\
Number of & 150 & & \\
Observation & & & \\
Log-likelihood & $-54.39^{*}$ & & \\
Chi-Squared & $98.74^{*}$ & &
\end{tabular}

Source: Computed from survey data, 2006.

The dependent variable is poverty status ( 1 if poor; 0 otherwise).

* Significant level at $1 \%$.

** Significant level at $5 \%$.

The result of the logit regression of determinants of poverty in the study area is presented in Table 4.10. In the model, the log-likelihood function (-54.39) and the Chi-square $\chi^{2}(98.74)$, were significant at $1 \%$ level. This shows that the model was well fitted. Five of the specified variables used in the model were statistically significant; they include Household size $\left(\mathrm{X}_{3}\right)$, dependency ratio $\left(\mathrm{X}_{4}\right)$, Household farm income $\left(\mathrm{X}_{5}\right)$ and other sources of agricultural information $\left(\mathrm{X}_{14}\right)$.

Household size as an independent variable has a positive coefficient of 0.84 and it was significant at alpha equal $1 \%$. This means that the household size is an important variable that affect poverty. That is, the higher the household size, the higher the probability of being poor. However, the marginal effect shows that household size is inelastic relative to poverty status; this is so because if household size increases by 1percent, the probability of being poor will increase by 0.20 percent. The dependency ratio $\left(\mathrm{X}_{4}\right)$ coefficient of -0.52 is significant at $5 \%$ level of significance. This means that as dependency ratio decreases, poverty increases since as many as 3 members of household are also working. The value of elasticity shows that if dependency ratio decreases by 1 percent, the probability of being poor will increase by 0.13 percent.

Household farm income $\left(\mathrm{X}_{5}\right)$ was one of the important factors that explained the poverty status of respondents. It was significant at $1 \%$ and negatively related to poverty status. This means that increases in household farm income will probably lead to reduction in poverty level. Also the marginal analysis reveals that if farm income increases by 1 per cent, the poverty status will remain unchanged. Land ownership $\left(\mathrm{X}_{13}\right)$ variable has a positive coefficient of 
1.07 but was not significant at 5\% critical level. Other source of agricultural information (X14) was also found to be statistically significant at $5 \%$ level and has a negative coefficient of 1.56 . This implied that as farmers obtain agricultural information from different sources such as radio, television amongst others, their probability of being poor is reduced. This buttressed the fact that information is a key to modern development.

\section{Conclusion and Recommendation}

Household size and farm size have significant relationship with poverty. The large number of family size and land degradation prevalent in the area translated into the high poverty incidence of $47 \%$ of the respondent. This is to say that so long as the issues of large family size and degrading farm land are left unaddressed the problem of poverty will be deepening. It is for this reason that we recommend that a Policy on land management practices and natural resource exploitation be reviewed or put in place where not already existing and adhered strictly by all relevant bodies and individuals as it will go a long way in conserving the natural resources and promoting crops yields with resultant increased farm income, all things being equal. The family planning policy/programme of a maximum of four children to a family to be revisited with a view to implementing it rigorously if the problems of large family size and unemployment are to be effectively addressed in the medium to long term.

\section{References}

Barbier, E. B. (2001). The Economics of Tropical Deforestation and Land Use: An Introduction to the Special Issue. Land Economics, 77(2), 155-171. http://dx.doi.org/10.2307/3147087

Blaikie, P., \& Brookfield, H. (1987). Land Degradation and Society. London: Metheun and Co.

Cleaver, K. M., \& Schreiber, G. A. (1993). The Population Environment and Agriculture Nexus in sub-Saharan Africa. In J. P. Srivastava, \& H. Alderman (Eds.), Agriculture and Environmental Challenges (pp. 199-214). Proceedings of the Thirteenth Agricultural Sector Symposium Washington D.C.: IBRD/The World Bank.

Cleaver, K. M., \& Schreiber, G. A. (1994). The Population Agriculture and Environment Nexus in sub-Saharan Africa. Washington D.C.: The World Bank.

Enete, A. A., \& Amusa, T. A. (2010). Challenges of Agricultural Adaptation to climate change in Nigeria. The Journal of Field Actions, 4.

Federal Office of Statistics. (1999). Poverty and Agricultural Factor of Nigeria. Federal Office Statistics, Abuja.

Food and Agriculture Organization. (2012). FAO Statistical Data base Hunger on-line data. Retrieved from http//:www.fao.org

Foster, J., Greer, J., \& Thorbecke, E. (1984). A Class of Decomposable Poverty Measure. Econometrica, 52, 761-766. http://dx.doi.org/10.2307/1913475

Grootaert, C. (1997). The Determinants of Poverty in Cote d' Ivoire in the 1980s. Journal of Economics, 6(2), 169-196.

IFAD. (1992). The State of World Rural Poverty: An Inquiry into Its Causes and Consequences. In I. Jazairy, M. Alamgir, \& T. Panuccio (Eds.). New York: New York University Press.

Nzenwa, G. C., \& Oboh, V. U. (2005). Effect of Household Endowments on Poverty among Farmers in Benue State. Proceedings of the $13^{\text {th }}$ Conference of the Agricultural Society of Nigeria, Benin.

Olaniyan, O. (2000). The Role of Household Endowment in Determining Poverty in Nigeria (pp. 9-19). Department of Economics, University of Ibadan, Nigeria.

Oyekale, A. S. (2012). Dynamics of Land Use, Degradation and sustainability of the Nigerian Agricultural Systems. African Journal of Agricultural Research, 7.

Pingali, P. L., \& Heisey, A. (1999). Cereal Crop productivity in Developing Countries. CIMMYT Economics Paper 99-03 Mexico D.F. CIMMYT.

Sen, A. K. (1976). Development: Which Way Now? The Economic Journal, 93, 754-761.

Tadesse, M., Kebede, B., \& Shimeles, A. (1999). Economic Reform, Growth and Poverty in Ethiopia: Evidence from Household Panel Surveys, final Report Submitted to the African Economic Research Consortium, Nairobi, December.

Tangen, S. (2002). Understanding the concept of productivity. Online Data (Google: Crop Productivity). 
Thorbecke, E. (2005). Multi-dimensional poverty-Conceptual and Measurement issues. Paper prepared for the Many Dimensions of Poverty International Conference, UNDP, International Poverty Centre, Brasilia, August 29-31.

United Nations Development Program. (1990). Human Development Report, New York: Oxford University Press.

Vosti, S. A., \& Reardon, T. (1997). Sustainability, Growth, and Poverty Alleviation: A policy and Agroecological Perspective. Baltimore: The John Hopkins University Press.

Wasson, R. (1987). Detection and measurement of land degradation processes. In A. Chisholm, \& Dumsday (Eds.), Land degradation: Problems and policies. London: Cambridge University Press.

World Bank. (1996). World Development Report. New York: Oxford University Press.

World Bank. (2000). World Development Indicators CDROM. Washington, D.C.: World Bank. 